\title{
IMPLEMENTASI KURIKULUM 2013 BIDANG STUDI BIOLOGI DALAM MENGEMBANGKAN SIKAP RELIGIUS SISWA DI MADRASAH ALIYAH
}

\author{
Achmad Sultoni \\ (Universitas Negeri Malang)
}

\begin{abstract}
Abstrak:
Akhir-akhir ini muncul beragam persoalan moral dan karakter pada remaja dan pelajar di Indonesia. Untuk mengatasi permasalahan ini, Kementerian Pendidikan dan Kebudayaan meminta sekolah-sekolah menerapkan Kurikulum 2013. Salah satu ciri kurikulum ini adalah adanya kompetensi sikap religius yang harus dicapai melalui seluruh bidang studi. Penelitian ini dimaksudkan untuk mengevaluasi penerapan Kurikulum 2013 bidang studi Biologi dalam mengembangkan kompetensi sikap religius siswa MAN 3 Malang. Dengan menggunakan pendekatan penelitian kualitatif model penelitian lapangan yang bersifat deskriptif diperoleh sejumlah temuan: pertama, pengembangan sikap religius dilakukan melalui penulisan rumusan tujuan pembelajaran dan penyampaian salam serta berdo'a di awal pembelajaran; kedua, pelaksanaan pengembangan sikap religius dilakukan dengan cara menyampaikan salam dan do'a di awal pembelajaran, menghubungkan materi pembelajaran dengan ajaran Islam, menyampaikan salam dan berdo'a kafaratul majlis di akhir pembelajaran, dan menegur siswa yang dianggap melanggar aturan Islam; ketiga, hambatan pengembangan sikap religius berupa tidak tersedianya contoh atau panduan penilaian kompetensi sikap religius.
\end{abstract}

Kata kunci: Kurikulum 2013, Kompetensi Sikap Religius, Biologi, Madrasah Aliyah. 


\begin{abstract}
:
Recently many kinds of youth and students' moral-character issues becomes a concern in Indonesia. To cope with these problems, Ministry of Education and Culture called for the implementation of Kurikulum 2013 (the national education curriculum). One of the curriculum characteristics is the religious competency to achieve in every school subjects including Biology. This research is aimed to evaluate implementation of Kurikulum 2013 in developing students' religious attitude through Biology class in MAN 3 Malang. The field research with qualitative approach and descriptive design found that: first, the development of students' religious competency is managed by teacher by formulating religious competency objective and accustoming salam and praying before the class begins; second, in the process of instruction, the teacher develop religious competency in four ways: salam and praying at introduction, finding relationship between Biology to Islamic teaching, salam and praying kafaratul majlis in closing the class, and admonishing students breaking the rules; last, this attitude development is constrained by the absence of evaluation guide.
\end{abstract}

Keywords: National Curriculum 2013, Religious Competency, Biology, Madrasah Aliyah.

\title{
A. Pendahuluan
}

Problematika moral dan karakter hingga saat ini masih menjadi masalah besar bangsa Indonesia. Persoalan-persoalan sosial budaya seperti korupsi, kejahatan seksual, tindak kekerasan di kalangan remaja, pergaulan yang mengarah pada seks bebas, serta penyalahgunaan narkoba dan zat adiktif lainnya belum juga dapat diselesaikan oleh pemerintah dan masyarakat. Tindak dan perilaku negatif dan merusak masyarakat ini terjadi di berbagai kalangan di masyarakat.

Di kalangan pelajar dan mahasiswa misalnya, persoalan moral dan karakter menampakkan kondisi yang memprihatinkan. Pacaran yang mengarah pada seks pra nikah, gaya hidup hura-hura, dan penyalahgunaan narkoba dan zat adiktif lainnya merupakan fenomena yang umum terjadi di berbagai kota, bahkan wilayah pinggiran kota. Padahal para remaja mendapatkan pendidikan agama di sekolah, dan masyarakat Indonesia dikenal sebagai masyarakat yang beragama.

Sebagian contoh persoalan moral di kalangan remaja adalah kasus bolosnya pelajar setingkat SMA di Madiun. Pada tanggal 16 April 2011, polisi Madiun menahan 12 pelajar setingkat SMA karena mereka bermain di warnet dengan pacarnya, padahal tidak lama lagi sebagian dari mereka akan mengikuti 
ujian nasional. Bahkan dua diantara mereka ditangkap di bilik warnet dalam keadaan tanpa pakaian ${ }^{1}$. Selain itu, penelitian yang dilakukan oleh Lembaga Studi Cinta dan Kemanusiaan dan Pusat Pelatihan Bisnis Humaniora (LSC dan K serta Pusbih) Yogyakarta pada tahun 1999 sampai 2002, menyebutkan hasil yang mengejutkan, bahwa 97,05\% dari 1.660 responden yang merupakan mahasiswa di 16 Perguruan Tinggi di Daerah Istimewa Yogyakarta menyatakan pernah melakukan aktivitas seksual pra nikah. ${ }^{2}$ Sementara itu, berdasarkan data yang ada, H. Hamdani Harahap, Ketua Dewan Pimpinan Daerah Gerakan Nasional Anti-Narkotika (Granat) Sumatra Utara, mengatakan bahwa pengguna narkoba di kalangan pelajar dan mahasiswa mencapai 921.695 orang, atau sekitar 4,7 persen dari total pelajar dan mahasiswa di Indonesia. ${ }^{3}$

Menyikapi permasalahan moral remaja ini, pemerintah melalui Kementerian Pendidikan dan Kebudayaan (Kemendikbud) meluncurkan kurikulum berbasis karakter sebagai solusinya. Kurikulum yang disebut juga Kurikulum 2013 dan mulai diterapkan secara terbatas pada tahun 2013 ini dimaksudkan untuk menyiapkan siswa-siswi yang berkarakter positif, seperti memiliki nilai religius, jujur, toleran, cinta tanah air dan seterusnya.

Nilai religius merupakan salah nilai karakter penting yang dikembangkan dalam kurikulum 2013. Aspek penting nilai karakter religius tercermin dari deskripsi nilai ini dalam kurikulum 2013, yaitu sikap dan perilaku yang patuh dalam melaksanakan ajaran agama yang dianutnya, toleran terhadap pelaksanaan ibadah agama lain, dan hidup rukun dengan pemeluk agama lain. ${ }^{4}$ Dari deskripsi ini dapat disimpulkan bahwa bila seseorang memiliki karakter religius, ia akan menjadi orang yang baik. Sebab orang yang religius bersikap taat dan patuh pada agamanya yang pasti mengajarkan kebaikan.

Tahun 2014 merupakan tahun kedua penerapan kurikulum 2013 bagi sekolah-sekolah di bawah Kemendikbud dan tahun pertama bagi sekolah di bawah Kementerian Agama (Kemenag) di berbagai daerah di Indonesia, termasuk di Malang, Jawa Timur. Penerapan kurikulum 2013 di berbagai sekolah di Malang perlu dievaluasi kelebihan dan kekurangannya sebagai bahan perbaikan. Salah satu aspek implementasi kurikulum 2013 yang menarik dan penting diteliti adalah penerapan pengembangan sikap siswa religius siswa. Sebab selain merupakan hal baru dan menjadi salah satu ciri khas kurikulum

\footnotetext{
${ }^{1}$ Harian Pagi Surya (edisi17 April 2011), 5.

${ }^{2}$ Iip Wijayanto, Sex In The Kost (Yogyakarta: CV. Qalam, 2003), 23.

3 "Gawat, 47 persen Pelajar Pengguna Narkoba", terakhir dirubah tanggal 19 Februari 2011, diakses tanggal 12 September 2014, http://www.antaranews.com/berita/246764/gawat-47-persen-pelajarpengguna-narkoba.

${ }^{4}$ Pusat Kurikulum, Pengembangan dan Pendidikan Budaya \& Karakter Bangsa: Pedoman Sekolah (Jakarta: TP, 2009), 9-10.
} 
2013, pengembangan sikap siswa oleh guru tidak boleh dilakukan dengan cara mengajarkan sikap secara langsung kepada siswa di kelas. Hal ini menuntut guru harus kreatif dalam mengembangkan sikap religius siswa melalui pemilihan media atau metode pembelajaran yang tepat, bahkan cara dan teknik evaluasi pembelajaran yang sesuai.

Tantangan lebih besar sesungguhnya dihadapi oleh guru bidang studi eksakta (Ilmu Pengetahuan Alam [IPA] atau Matematika) dalam mengembangkan sikap religius siswa, sebab umumnya kajian atau uraian tentang alam semesta tidak terkait secara langsung dengan sikap religius. Dengan demikian guru IPA dituntut lebih cermat dan kreatif dalam mengembangkan sikap religius siswa melalui bidang studi yang ia ajarkan. Oleh karena itu, menarik untuk diteliti bagaimana upaya dan kreatifitas guru IPA, salah satunya guru Biologi, dalam mengimplementasikan aturan baru tersebut.

Dalam penelitian ini, Madrasah Aliyah Negeri (MAN) 3 Malang sengaja dipilih sebagai sasaran penelitian karena beberapa pertimbangan, salah satunya adalah bahwa madrasah merupakan sekolah berbasis agama Islam, yang diasumsikan memberi perhatian lebih pada pengembangan sikap religius siswa. Selain itu, MAN 3 Malang termasuk salah satu madrasah aliyah berkualitas dan favorit di Wilayah Jawa Timur. Hal ini antara lain karena prestasi-prestasi yang diraih sekolah ini, baik dalam bidang akademik maupun non akademik, di tingkat regional, nasional, bahkan internasional. 5 Selain itu, diantara fasilitas yang dimiliki MAN 3 Malang dan menjadi kelebihannya adalah ma'had atau asrama siswa yang dirancang sedemikian rupa utuk menghasilkan lulusan yang berkualitas secara intelektual dan spiritual. Dengan demikian diharapkan implementasi kurikulum 2013 dalam aspek pengembangan sikap religius siswa di lokasi penelitian berlangsung dengan optimal.

Penelitian tentang implementasi kurikulum 2013 hingga menjelang akhir tahun 2014 belum banyak dilakukan. Hal ini wajar karena implementasinya baru berjalan satu tahun lebih sedikit. Adapun penelitian mengenai pengembangan karakter atau sikap siswa telah banyak dilakukan. Misalnya pengembangan karakter siswa melalui budaya lokal, diantaranya dilakukan oleh Masita (2012) yang meneliti pendidikan karakter berdasarkan budaya masyarakat muslim di Bima, dan juga Nuril (2013) yang meneliti tentang strategi pendidikan karakter di SMAN Dompu melalui penciptaan budaya sekolah yang kondusif. Sementara

5 Di tingkat nasional misalnya, pada tahun 2013, siswa sekolah ini meraih medali emas pada Olimpiade Sains Nasional (OSN). Sementara di tingkat internasional, pada tahun yang sama, siswi MAN 3, Aulia Safitri, yang mewakili Indonesia berhasil menempati posisi runner up pada ajang Global Art Internasional Competition di Bali. Sumber: "Prestasi" Profil Madrasah, diakses tanggal 12 Agustus 2014, http://www.man3malang.com/tag/prestasi/page/1. 
itu, terkait dengan penerapan pendidikan karakter dalam pembelajaran, Slamet Suyanto (t.tahun), mengadakan penelitian tentang pendidikan karakter yang efektif melalui pembelajaran integral, yakni nilai karakter dikembangkan secara terpadu melalui semua pelajaran. Adapun tentang karakter religius, diantaranya adalah penelitian yang dilakukan Hanni Juwaniah (2013) memfokuskan pada penerapan nilai-nilai religius pada siswa MIN Bawu, Jepara, dan Jumarudin (2014) yang mengkaji pengembangan pembelajaran humanis religius di sekolah dasar. Penelitian-penelitian tersebut tidak ada yang membahas secara spesifik tentang penerapan nilai karakter sikap religius dalam bidang studi tertentu, dalam hal ini pada bidang studi umum, yakni Biologi.

Berdasarkan latar belakang dan kerangka berpikir diatas, penelitian ini dimaksudkan untuk menelaah bidang yang belum pernah dikaji sebelumnya, yaitu implementasi kurikulum 2013 bidang studi Biologi kelas X dalam mengembangkan sikap religius siswa di salah satu sekolah keagamaan (Islam) di kota Malang, yaitu MAN 3 Malang. Dalam lingkup yang lebih luas, penelitian ini dapat dipandang sebagai upaya untuk menemukan strategi yang efektif dalam mengembangkan sikap religius siswa melalui bidang studi ilmu alam demi membantu terwujudnya tujuan mulia pendidikan bangsa Indonesia, yakni menghasilkan generasi muda yang beriman dan bertaqwa kepada Tuhan Yang maha Esa.

Mempertimbangkan uraian di atas, maka permasalahan umum yang hendak dicari jawabannya melalui penelitian ini adalah bagaimana implementasi Kurikulum 2013 bidang studi Biologi dalam mengembangkan sikap religius siswa kelas $\mathrm{X}$ di MAN 3 Malang. Permasalahan umum ini selanjutnya dirinci menjadi tiga, yaitu: pertama, bagaimana perencanaan implementasi Kurikulum 2013 Bidang Studi Biologi Kelas X dalam mengembangkan sikap religius siswa di MAN 3 Malang? kedua, bagaimana pelaksanaan implementasi Kurikulum 2013 Bidang Studi Biologi kelas X dalam mengembangkan sikap religius siswa di MAN 3 Malang? dan ketiga, apa hambatan implementasi Kurikulum 2013 Bidang Studi Biologi kelas X dalam mengembangkan sikap religius siswa di MAN 3 Malang?

Adapun tujuan penelitian ini adalah teridentifikasinya implementasi Kurikulum 2013 bidang studi Biologi kelas X dalam mengembangkan sikap religius siswa di MAN 3 Malang dalam aspek perencanaan, pelaksanaan, dan hambatan. Hasil penelitian ini diharapkan bermanfaat sebagai bahan evaluasi dan referensi implementasi kurikulum 2013 dalam hal pengembangan sikap religius siswa melalui bidang studi ilmu alam, seperti Biologi, terutama di sekolah berciri agama (Islam). 


\section{B. Metode Penelitian}

Sesuai dengan tujuan penelitian ini, yaitu mendeskripsikan implementasi kurikulum 2013 dalam hal pengembangan sikap religius melalui bidang studi Biologi, maka pendekatan yang dipandang tepat adalah kualitatif dengan rancangan deskriptif. sementara terkait dengan lokasi penelitian, penelitian ini diklasifikasikan termasuk jenis penelitian lapangan (field research). Pemilihan pendekatan dan rancangan deskriptif kualitatif bertolak dari pandangan Bogdan dan Biklen6 tentang tujuan dan fokus yang diteliti, yaitu ingin menemukan deskripsi berupa uraian sistematis dan faktual mengenai implementasi kurikulum 2013 bidang studi Biologi dalam mengembangkan sikap religius siswa. Adapun cakupan implementasi ini ada 3, yaitu: perencanaan, penerapan, dan hambatan.

Penelitian ini dilakukan pada bulan September-Oktober 2014. Adapun sumber data dalam penelitian ini adalah dokumen rencana pelaksanaan pembelajaran (RPP), guru Biologi (ibu DA), siswa (kelas X A2, X F dan X D), dan interaksi belajar antara guru dan siswa selama proses pembelajaran. Untuk memperoleh data yang diperlukan, penelitian ini menjadikan peneliti sebagai instrumen penelitian (human instrument), dibantu oleh alat pengumpul data berupa panduan kodifikasi data dan pedoman wawancara. Sedangkan teknik pengumpulan data yang digunakan adalah dokumentasi, observasi, dan wawancara. Analisis data yang digunakan dalam penelitian ini adalah teknik deskriptif kualitatif model Miles dan Huberman. ${ }^{7}$

\section{Hasil Penelitian dan Pembahasan}

1. Perencanaan Pengembangan Sikap Religius Siswa melalui bidang studi Biologi kelas X di MAN 3 Malang8

Untuk persiapan pembelajaran tahun pelajaran 2014/2015 semester gasal mata pelajaran Biologi kelas X, subyek penelitian menyusun sebuah buku RPP sebagai panduan pembelajaran selama satu semester. Dalam semester gasal terdapat lima bab yang akan dipelajari siswa, dan pada setiap bab dibuatkan sebuah RPP. Bab I membahas ruang lingkup Biologi, kerja ilmiah dan keselamatan kerja, serta karir berbasis Biologi. Materi bab II adalah berbagai tingkat keanekaragaman hayati, dan dilanjutkan bab II yang mengkaji virus:

\footnotetext{
${ }^{6}$ Bogdan, R.C. \& Biklen, S.K, Qualitative Research for Education: An Introduction to Theory and Methods (Boston: Allyn \& Bacon, Inc., 1982), 82.

${ }^{7}$ Sugiyono, Memahami Penelitian Kualitatif (Bandung: Penerbit Alfabeta, 2010), 90-91.

${ }^{8}$ Data pada sub bab ini bersumber dari Rancangan Pelaksanaan Pembelajaran (RPP) Matapelajaran Biologi Kelas X Tahun Pelajaran 2014/2015 yang disusun oleh subyek penelitian: ibu DA.
} 
ciri, dan peranannya dalam kehidupan. Adapun tema bab IV adalah archaebacteria dan eubacteria: ciri dan peranannya, dan diakhiri bab $\mathrm{V}$ tentang protista: ciri dan karakteristik, dan peranannya dalam kehidupan.

Dalam setiap RPP yang dibuat guru, selalu terdapat komponen berikut: kompetensi (yang terdiri dari rumusan Kompetensi Inti (KI), KD, indikator pencapaian $\mathrm{KD}$, dan tujuan pembelajaran), materi ajar, metode pembelajaran, kegiatan pembelajaran (yang berisi tahap pendahuluan, kegiatan inti, dan penutup), sumber/bahan/alat, dan penilaian (yang terdiri dari teknik dan instrumen penilaian). Berkenaan dengan implementasi pengembangan sikap religius yang terdapat dalam RPP, berikut ini temuan penelitian yang didapat.

a. Komponen kompetensi dan tujuan pembelajaran

Pada kompenen kompetensi, yang merupakan acuan perancangan kegiatan pembelajaran, penerapan pengembangan sikap religius di RPP terdapat pada KI 1 dan KD 1 yang ditetapkan pemerintah dalam kurikulum 2013. Selain itu, para guru secara mandiri membuat indikator pencapaian kompetensi dan rumusan tujuan pembelajaran untuk mengembangkan kompetensi sikap religius.

Dari kajian terhadap lima buah RPP bidang studi Biologi semester gasal kelas X ini teridentifikasi 3 Kompetensi Dasar (KD) sikap religius yang hendak dikembangkan oleh subyek penelitian pada diri siswa. Berikut ini rumusan KD sikap religius semester gasal beserta tema tempat KD dikembangkan dan durasi waktu pembelajarannya.

Pada bab I, ruang lingkup biologi, dan bab II, keanekaragaman hayati, KD sikap religius yang dikembangkan adalah: mengagumi keteraturan dan kompleksitas ciptaan Tuhan tentang keanekaragaman hayati, ekosistem, dan lingkungan hidup. Durasi waktu yang dibutuhkan untuk mempelajari dua tema ini adalah 12 jam pelajaran.

Pada bab III, virus, dan bab IV, archaebacteria dan eubacteria, KD sikap religius yang dikembangkan adalah: menyadari dan mengagumi pola pikir ilmiah dalam kemampuan mengamati bioproses. Dua bab ini dirancang oleh guru dipelajari oleh siswa selama 15 jam pelajaran.

Pada bab V, protista, KD sikap religius yang dikembangkan adalah: peka dan peduli terhadap permasalahan lingkungan hidup, menjaga dan menyayangi lingkungan sebagai manifestasi pengamalan ajaran agama yang dianutnya. Tema bab $\mathrm{V}$ ini direncanakan selesai dikaji selama 9 jam pelajaran.

Meski lima RPP tersebut masing-masing memiliki KD sikap religius, tapi tidak seluruh RPP memiliki indikator kompetensi sikap religius dan rumusan tujuan pembelajaran yang berkenaan dengan sikap religius. Pada 
RPP pertama, materi pokok ruang lingkup biologi, terdapat empat KD (salah satunya adalah KD sikap religius) yang memiliki tujuh belas indikator pencapaian $\mathrm{KD}$, dan tidak satupun indikator ini terkait dengan KD sikap religius. Hal yang sama juga terjadi pada rumusan tujuan pembelajaran yang tidak mencantumkan tujuan mengenai sikap religius. Ketiadaan indikator kompetensi dan rumusan tujuan pembelajaran berkenaan dengan sikap religius pada RPP pertama juga terjadi pada RPP kedua, materi pokok keanekaragaman hayati.

Sementara itu, kondisi berbeda terjadi pada RPP ketiga (materi pokok virus) dan keempat (archaebacteria dan eubacteria). Meskipun pada RPP ini juga tidak ditemukan indikator pencapaian kompetensi terkait sikap religius, ditemukan satu rumusan tujuan pembelajaran yang berkenaan dengan sikap religius, yaitu: "menyadari dan mengagumi pola pikir ilmiah dalam kemampuan mengamati bioproses, serta peka dan peduli terhadap permasalahan lingkungan hidup, menjaga dan menyayangi lingkungan". Keadaan yang sama terdapat pada RPP bab protista yang tidak menyebutkan indikator kompetensi sikap religius, tapi dalam salah satu rumusan tujuan pembelajaran disebutkan: "menyadari dan mengagumi pola pikir ilmiah dalam kemampuan mengamati bioproses, serta responsif dan proaktif dalam observasi dan eksperimen."

b. Komponen kegiatan pembelajaran

Guru membagi kegiatan pembelajaran menjadi 3 tahap, yaitu; pendahuluan, kegiatan inti, dan penutup. Dalam pendahuluan, kegiatan yang dilakukan guru dimaksudkan untuk mengkondisikan siswa untuk belajar. Sedangkan dalam kegiatan inti, dipilih 5 aktifitas pendekatan saintifik. Adapun untuk penutup, aktifitas yang dilakukan adalah penugasan dan refleksi.

Bagian pendahuluan dalam seluruh RPP yang dirancang guru umumnya berisi kegiatan salam dan doa, pengkondisian kelas, apersepsi, motivasi, penyajian prasyarat, dan penyampaian tujuan pembelajaran. Dari kegiatan-kegiatan tersebut, aktifitas menyampaikan salam dan berdoa digunakan oleh guru untuk mengembangkan sikap religius siswa. Sedangkan kegiatan pengkondisian kelas, apersepsi dan seterusnya tidak menampakkan adanya maksud mengembangkan sikap religius. Pemahaman bahwa tiga kegiatan tersebut tidak ditujukan mengembangkan sikap religius muncul karena kegiatan-kegiatan tersebut tertulis di RPP tanpa keterangan apapun mengenai isi atau tujuan kegiatan tersebut. Hal ini berbeda dengan kegiatan salam dan berdoa yang di RPP tertulis ditujukan untuk mengembangkan sikap religius. 
Sementara itu, dalam kegiatan inti, guru menggunakan pendekatan saintifik untuk membelajarkan siswa dengan lima langkah: mengamati, menanya, mengeksplorasi/mengumpulkan data, mengasosiasi, dan mengkomunikasikan. Dalam kegiatan inti ini, aspek yang dikembangkan oleh guru adalah sikap sosial, pengetahuan dan ketrampilan siswa. Tidak ditemukan adanya aktifitas dalam kegiatan inti dalam RPP yang secara eksplisit mengembangkan sikap religius.

Sedangkan dalam kegiatan penutup, ragam kegiatan yang dirancang oleh guru adalah refleksi atau umpan balik dan pemberian tugas, baik penugasan terstruktur (PT) maupun kegiatan mandiri tidak terstruktur (KMTT). Dalam kegiatan refleksi atau umpan balik, dokumen RPP tidak menjelaskan seperti apa aktifitas yang dilakukan guru dan siswa. Dengan demikian tidak bisa ditentukan secara pasti apakah sikap religius dikembangkan oleh guru melalui kegiatan ini.

Adapun untuk aktifitas penugasan, tugas yang harus dilakukan siswa disesuaikan dengan tema pembelajaran. Meskipun begitu, nampak bahwa dalam aktifitas ini guru cenderung mengembangkan aspek pengetahuan atau ketrampilan siswa. Berikut ini contoh aktifitas pemberian tugas oleh guru: 1) Carilah permasalahan biologi yang terjadi dalam kehidupan sehari-hari (Penugasan terstruktur pertemuan ke 3 bab I); 2) Deskripsikan keselamatan kerja di laboratorium dan dari berbagai sumber pelajaran (KMTT pada pertemuan ke 4 bab I); 3) Carilah pemanfaatan keanekaragaman hayati yang sudah dilakukan dan sebutkan peluang pemanfaatannya secara berkelanjutan dalam ekonomi kreatif (Penugasan terstruktur pertemuan ke 2 bab II).

Dengan demikian, hasil telaah terhadap tiga komponen kegiatan pembelajaran tersebut diperoleh temuan bahwa sikap religius oleh guru dikembangkan melalui penyampaian salam dan do'a pada pendahuluan, yaitu di awal pembelajaran. Adapun pada tahap kegiatan inti dan penutup tidak ditemukan secara eksplisit rancangan aktifitas pembelajaran untuk mengembangkan sikap religius.

c. Komponen evaluasi

Sementara itu, terkait dengan rencana evaluasi pembelajaran, guru menggunakan beragam jenis penilaian untuk mengetahui kemampuan dan sikap siswa, yaitu: penilaian tes tertulis, penilaian kinerja, penilaian proyek, penilaian portofolio. Adapun teknik penilaian yang digunakan antara lain penugasan, tes tulis obyektif dan tes tulis subyektif untuk menilai kompetensi kognitif siswa, portofolio untuk menilai kompetensi 
ketrampilan, dan lembar observasi atau ceklis untuk menilai kompetensi ketrampilan psikomotor dan sikap.

Meskipun dalam dokumen RPP terdapat beragam jenis dan teknik penilaian yang digunakan, tidak ditemukan adanya penilaian terhadap sikap religius siswa. Memang benar ada sejumlah lembar observasi atau ceklis untuk menilai sikap. Akan tetapi lembar penilaian tersebut hanya menilai sikap sosial siswa, bukan sikap religius. Sebagai contoh, pada RPP bab keanekaragaman hayati, salah satu lembar penilaian sikap berupa lembar observasi dirancang untuk mengetahui sikap siswa terkait dengan ketrampilan bertanya, berkomunikasi, kerjasama, ketepatan waktu, dan partisipasi. Sedangkan pada RPP bab virus, instrumen penilaian sikap berupa ceklis digunakan untuk mengumpulkan data mengenai sikap disiplin, kerjasama, kejujuran, kepedulian, dan tanggung jawab.

Berdasarkan pemaparan data diatas dapat disimpulkan bahwa dalam dokumen RPP Biologi kelas X yang dibuat subyek penelitian ditemukan dua kegiatan pembelajaran sebagai wujud implementasi pengembangan sikap religius siswa, yaitu: guru menuliskan rumusan tujuan pembelajaran untuk mengembangkan sikap religius siswa, dan guru dan siswa mengucapkan salam dan berdo'a di awal pembelajaran. Temuan ini menunjukkan bahwa penerapan pengembangan sikap religius siswa dalam RPP tersebut masih minim dan belum sesuai dengan keinginan kurikulum 2013, sebab kurikulum 2013 mengamanatkan agar guru merancang RPP yang didalamnya terdapat pengembangan sikap religius siswa melalui kegiatan pembelajaran (secara tidak langsung) dan penilaian. ${ }^{9}$ Hal ini juga menunjukkan bahwa upaya mengembangkan sikap religius siswa dalam RPP Biologi tersebut masih bisa dimaksimalkan, karena dari 5 bab yang diajarkan di semester gasal, ternyata hanya tiga RPP yang memiliki tujuan kompetensi sikap religius.

Dalam perspektif ilmu pembelajaran, kondisi ini bukan merupakan keadaan yang ideal, dan rentan menimbulkan tidak optimalnya pelaksanaan pembelajaran. Alasannya adalah karena RPP dibuat untuk dijadikan panduan dalam mengajar oleh guru. ${ }^{10}$ Jika panduannya tidak lengkap, maka kegiatan pembelajaran yang diselenggarakan juga potensial

${ }^{9}$ Salinan Lampiran Peraturan Menteri Pendidikan dan Kebudayaan Republik Indonesia Nomor 65 Tahun 2013 tentang Standar Proses Pendidikan Dasar dan Menengah, 7, diakses tanggal 13 September 2014, http://bsnp-indonesia.org/id/wp-content/uploads/2009/06/03.-A.-SalinanPermendikbud-No.-65-th-2013-ttg-Standar-Proses.pdf.

${ }^{10}$ Kunandar, Guru Profesional: Implementasi KTSP dan Sukses dalam Sertifikasi Guru (Jakarta: PT RajaGrafindo Persada, 2007), 263. 
tidak sempurna. Dengan istilah lain, RPP tersebut perlu diperbaiki dan dilengkapi -terutama aspek yang terkait dengan sikap religius- agar dapat menjadi RPP yang baik yang bisa dijadikan panduan dalam melaksanakan pembelajaran untuk mengembangkan sikap religius siswa.

Pertanyaan yang muncul kemudian adalah mengapa kondisi tidak ideal ini terjadi. Jawaban persoalan ini tidak sederhana, sebab penerapan Kurikulum 2013 melibatkan banyak aspek dan pihak. Ada kemungkinan faktor yang menjadi penyebabnya adalah keterbatasan waktu dalam memahami berbagai aturan dan konsep Kurikulum 2013 dan implementasinya. Hal ini didukung pendapat banyak pihak bahwa kurikulum 2013 tergesa-gesa diterapkan di sekolah-sekolah. ${ }^{11}$

Dari sudut pandang lain, bila ditinjau dari pendekatan pembelajaran yang dipilih, pendekatan yang digunakan dalam merancang aktifitas pembelajaran guna mengembangkan sikap religius siswa sudah tepat, yakni dengan menggunakan pendekatan saintifik dengan lima langkahnya. ${ }^{12}$ Sayangnya setelah merancang aktifitas pembelajaran dengan pendekatan saintifik, subyek penelitian tidak melanjutkan dengan merancang aktifitas pembelajaran untuk mengembangkan KD sikap religius siswa sebagaimana yang telah ditetapkan dalam kurikulum 2013.

Terlepas dari apapun penyebabnya, sesuai dengan amanat kurikulum 2013, guru seharusnya berupaya merancang RPP Biologi kelas $\mathrm{X}$ yang di dalamnya terkandung kegiatan pembelajaran untuk mengembangkan kompetensi sikap religius sesuai dengan aturan kurikulum 2013. Untuk melakukan hal tersebut, guru perlu memperhatikan dan memahami KD sikap religius yang akan dikembangkan, dan selanjutnya menentukan langkah pembelajaran untuk mencapai KD tersebut. Sesuai dengan peraturan pemerintah, penentuan langkah pembelajaran ini seharusnya "berpijak" pada atau bermula dari kegiatan pembelajaran yang menggunakan pendekatan saintifik untuk mengembangkan KD 3 dan KD 4.

Sebagai contoh, untuk mencapai salah satu kompetensi dasar sikap religius bidang studi Biologi kelas $\mathrm{X}$, yaitu: "mengagumi keteraturan dan

11 "Tiga Masalah Guru dalam Implementasi Kurikulum 2013", dirubah terakhir tanggal 16 Oktober 2014, diakses tanggal 22 November 2014, http://news.okezone.com/read/2014/10/16/65/1052959/tiga-masalah-guru-dalam-implementasikurikulum-2013.

12 Salinan Lampiran IV Peraturan Menteri Pendidikan dan Kebudayaan Republik Indonesia Nomor 81a Tahun 2013 Tentang Implementasi Kurikulum, 6, Diakses Tanggal 10 September 2014, http://luk.staff.ugm.ac.id/atur/bsnp/Permendikbud81A-2013ImplementasiK13Lengkap.pdf. 
kompleksitas ciptaan Tuhan tentang keanekaragaman hayati, ekosistem dan lingkungan hidup," guru dapat melakukannya melalui bab bakteri. Setelah guru meminta siswa mengkaji ragam bakteri dan kehidupannya dengan menggunakan pendekatan saintifik, guru dapat meminta siswa mengkaitkan keteraturan dan kompleksitas bakteri dengan kemahakuasaan dan kemahabijaksanaan Allah yang mampu menciptakan mahluk yang amat kecil dan kompleks.

Sementara itu, ditinjau dari aspek keselarasan RPP, dokumen RPP tersebut juga menampakkan kekurangan berupa tidak selarasnya antar komponen RPP. Pertama, KD sikap religius tidak diikuti dengan perumusan tujuan pembelajaran sikap religius. Padahal tujuan pembelajaran seharusnya dirumuskan dari KD.13 Dengan demikian, jika terdapat KD sikap religius dalam sebuah RPP, seharusnya dibuat rumusan tujuan pembelajaran berkenaan dengan sikap religius pula. Selanjutnya, aspek kompetensi (berupa rumusan KD dan tujuan pembelajaran) tidak selaras dengan komponen aktifitas pembelajaran secara keseluruhan, dimana hanya dalam kegiatan pendahuluan terdapat upaya mengembangkan sikap religius siswa. Sedangkan dalam kegiatan inti dan penutup tidak ada aktifitas untuk mengembangkan sikap religius. Ketidakselarasan ini berlanjut pada tiadanya penilaian sikap religius dalam komponen evaluasi, padahal dalam RPP terdapat KD sikap religius, yang mana seharusnya diukur oleh komponen penilaian sikap, dalam hal ini penilaian sikap religius, ${ }^{14}$ seperti dengan menggunakan metode observasi, penilaian antar peserta didik atau penilaian diri. Secara keseluruhan, ketidakselarasan antar komponen RPP ini bertentangan dengan salah satu prinsip penyusunan RPP, yaitu penekanan pada keterkaitan dan keterpaduan antar komponen RPP. 15 Maksudnya adalah bahwa KD, indikator pencapaian kompetensi, tujuan pembelajaran, materi pembelajaran, kegiatan pembelajaran, penilaian, dan sumber belajar saling terkait sebagai sebuah keutuhan yang terpadu dalam sebuah pengalaman belajar.

${ }^{13}$ Salinan Lampiran Peraturan Menteri Pendidikan dan Kebudayaan Republik Indonesia Nomor 65 Tahun 2013 tentang Standar Proses Pendidikan Dasar dan Menengah, 6.

14 Kementerian Agama Direktorat Pendidikan Madrasah Direktorat Jenderal Pendidikan Islam. Pedoman Penilaian Hasil Belajar Peserta Didik Tingkat Madrasah Aliyah (MA). (Jakarta: TP., 2014), 7.

${ }^{15}$ Salinan Lampiran Peraturan Menteri Pendidikan dan Kebudayaan Republik Indonesia Nomor 65 Tahun 2013 tentang Standar Proses Pendidikan Dasar dan Menengah, 7. 
2. Pelaksanaan Pengembangan Sikap Religius Siswa melalui bidang studi Biologi kelas X di MAN 3 Malang

a. Pelaksanaan kegiatan pembelajaran

Berbeda dengan tahap perencanaan (dokumen RPP), dalam pelaksanaan kegiatan pembelajaran ditemukan bahwa guru melaksanakan pengembangan sikap religius siswa dalam 3 tahap kegiatan pembelajaran; pendahuluan, kegiatan inti dan penutup. Dalam pelaksanaan pembelajaran di kelas, guru mengembangkan sikap religius siswa melalui beberapa cara. Pertama, melalui ucapan salam dan do'a di awal pertemuan (kegiatan pendahuluan), kedua, mengaitkan materi pembelajaran dengan ajaran Islam saat sedang menjelaskan materi pelajaran (kegiatan inti), ketiga, melalui ucapan salam dan do'a di akhir pertemuan (kegiatan penutup), dan keempat, melalui teguran pada siswa yang dianggap melanggar aturan agama, baik pada kegiatan pendahuluan, inti, atau penutup.

Berkenaan dengan cara pertama, yakni melalui ucapan salam dan do'a di awal pertemuan, guru membiasakan untuk mengucapkan: assalamu 'alaikum warahmatullohi wa barokatuh dan siswa menjawabnya. Guru kemudian meminta siswa berdo'a pada saat memulai pembelajaran. Berbeda dengan ucapan salam yang disampaikan dengan suara nyaring oleh guru dan dijawab secara nyaring juga oleh siswa, saat melantunkan do'a, siswa berdo'a dengan suara lirih dan isi do'a tergantung siswa masing-masing.

Sementara itu, untuk cara kedua, yakni guru mengaitkan materi pembelajaran dengan ajaran Islam saat sedang menjelaskan materi pelajaran, guru melakukannya dengan menghubungkan tema yang sedang dibahas dengan sebagian aturan Islam yang relevan. Sebagai contoh, suatu saat guru membahas tentang macam-macam virus dan bahayanya, seperti bahaya virus HIV, ia menghubungkan hal tersebut dengan ajaran Islam mengenai larangan berhubungan seks pra nikah. ${ }^{16}$ Hal yang sama juga dilakukan guru saat menjelaskan mengenai macam-macam virus, yang kemudian ia kaitkan dengan perintah agama Islam untuk menjaga kebersihan dengan cara mandi17. Dalam dua kejadian tersebut, guru menggunakan metode tanya-jawab dan ceramah.

Adapun pengembangan sikap religius melalui cara ketiga, yakni salam dan do'a pada kegiatan penutup, dilakukan guru dengan cara mengucapkan salam yang langsung dijawab siswa. Setelah itu, ia meminta siswa untuk melantunkan do'a "kafaratul majlis": subhaanakallaahumma

\footnotetext{
${ }^{16}$ Observasi pembelajaran di kelas pada tanggal 15 Oktober 2014 pukul 13.50 WIB.

${ }^{17}$ Observasi pembelajaran di kelas pada tanggal 16 Oktober 2014 pukul 08.00 WIB.
} 
wabihamdika asyhadu allaa ilaaha illaa anta subhaanaka innii kuntu minad dhoolimin. ${ }^{18}$

Sedangkan pengembangan sikap religius pada cara keempat, guru menegur siswa yang dianggap melanggar aturan Islam saat pembelajaran berlangsung. Teguran ini dilakukan guru secara kondisional tergantung waktu terjadinya pelanggaran, kadang pada kegiatan pendahuluan, kegiatan inti, atau pada kegiatan penutup. Salah satu teguran yang dilakukan guru pada siswa, misalnya terjadi saat awal pembelajaran ketika guru memeriksa hasil kerja siswa yang membuat poster tentang bakteri. Guru memandang siswa melanggar aturan Islam karena membuat poster yang berisi model permainan dadu. ${ }^{19}$

b. Pelaksanaan evaluasi

Dalam sejumlah kesempatan observasi saat guru melaksanakan ulangan harian, aktifitas mengembangkan sikap religius dilakukan guru melalui salam dan do'a pada kegiatan pembuka dan penutup. Sedangkan pada aspek utama kegiatan ulangan harian, guru nampak terfokus menilai aspek pengetahuan siswa melalui soal-soal tulis. Indikasinya adalah semua butir soal ulangan harian tidak terkait sikap religius maupun dengan ajaran Islam. Selama observasi juga tidak ditemukan aktifitas guru untuk mengetahui sikap religius siswa. ${ }^{20}$

Dari uraian tentang pelaksanaan pengembangan sikap religius melalui pembelajaran diatas dapat disimpulkan terdapat 4 cara yang dilakukan subyek penelitian dalam mengembangkan sikap religius siswa, yaitu: 1) pada kegiatan pendahuluan, guru mengembangkan sikap religius siswa dengan cara penyampaian salam dan do'a, 2) dalam kegiatan inti dilakukan dengan cara menghubungkan materi pembelajaran dengan ajaran Islam, 3) pada penutup, pengembangan sikap religius dilakukan melalui salam dan do'a kafaratul majlis, dan 4) teguran terhadap siswa yang dianggap melanggar aturan Islam. Berikut ini pembahasan terhadap temuan diatas yang dibagi menjadi 3 sub tema dengan menggabungkan pembahasan salam dan do'a di pendahuluan dan penutup menjadi satu.

1) Salam dan do'a (di awal dan di akhir pertemuan)

${ }^{18}$ Observasi pembelajaran di kelas pada tanggal 15 Oktober 2014 pukul 13.50 WIB dan tanggal 16 Oktober 2014 pukul 08.00 WIB.

${ }^{19}$ Observasi pembelajaran di kelas pada tanggal 15 Oktober 2014 pukul 13.50 WIB dan tanggal 16 Oktober 2014 pukul 08.00 WIB.

${ }^{20}$ Observasi pembelajaran di kelas pada tanggal 15 Oktober 2014 pukul 13.50 WIB dan tanggal 16 Oktober 2014 pukul 08.00 WIB. dan lembar soal ulangan harian. 
Penggunaan aktifitas salam dan do'a yang dilakukan di awal dan akhir kegiatan pembelajaran untuk mengembangkan sikap religius siswa di MAN 3 Malang nampaknya terinspirasi dari kebiasaan para guru agama Islam atau guru yang beragama Islam ketika mengajar di lembaga tersebut. Hal ini merupakan tindakan yang baik karena memperkaya metode pengembangan sikap religius siswa, meskipun tujuan aktifitas ini tidak berhubungan langsung dengan kompetensi sikap religius yang ditetapkan untuk bidang studi Biologi kelas X.

Cara ini memang nampak biasa bagi sebagian orang karena sering dilakukan di berbagai sekolah berciri khas Islam di Indonesia, tapi bila dilakukan dengan benar sesungguhnya dapat meningkatkan sikap religius atau keimanan siswa. Dalam hal salam, sebaiknya guru dan siswa melakukannya dengan penuh kesadaran dan mengetahui inti atau makna ucapan salam, sehingga dapat muncul kesadaran dalam diri siswa untuk saling berbuat baik, yaitu mendoakan orang lain agar selamat. Selain itu, menurut Said Agil Al-Munawwar, menyebarkan salam juga dapat meningkatkan persatuan antar umat Islam dalam kehidupan di masyarakat. ${ }^{21}$ Untuk bisa mencapai maksud ini, guru perlu menjelaskan dan menyadarkan kepada siswa bahwa hikmah Allah menyuruh menyebarkan salam adalah agar manusia mendoakan orang lain selamat.

Sementara itu, akfititas berdo'a -baik doa memohon diberi ilmu di awal pertemuan ataupun do'a kafaratul majlis di akhir pertemuan- sangat bermanfaat dalam meningkatkan iman seseorang, karena menurut Nurkholish Madjid, do'a adalah titik sentral pertumbuhan kesadaran ketuhanan. ${ }^{22}$ Disamping itu, dalam sebuah hadits disebutkan do'a adalah ibadah; suatu bentuk penghambaan diri kepada Allah, ${ }^{23}$ yang apabila dilakukan akan membuat pelakunya semakin dekat kepada Allah. ${ }^{24}$

Do'a yang baik, yang mudah meningkatkan iman pelakunya, adalah do'a yang dilakukan dengan suara lembut, khusyuk (penuh kesadaran dan penghayatan), ikhlas, rendah hati, dan merasa butuh dan hina di hadapan Allah.25 Doa memohon diberi ilmu yang dilakukan

${ }^{21}$ Said Agil Al-Munawwar, Islam dan Masa Depan Umat (Jakarta: Zikrul Hakim, 2004), 61.

${ }^{22}$ Nurcholish Madjid, Islam Agama Peradaban: Membangun Makna dan Relevansi Doktrin Islam dalam Sejarah (Jakarta: Paramadina, 1999), 200.

${ }^{23}$ Sayyid Sabiq, Fikih Sunnah 4, Terj. Mahyuddin Syaf (Bandung: PT. Alma'arif, t.thn.), 268.

${ }^{24}$ Mursalim, “Do’a dalam Perspektif al-Qur'an”, Jurnal Al-Ulum vol. 11, no. 1 (Juni 2011), 63.

${ }^{25}$ Mursalim, “Do’a dalam Perspektif al-Qur'an”, 73. 
siswa di awal pertemuan dapat meningkatkan sikap religius siswa dalam hal munculnya kesadaran bahwa Allah maha tahu, siswa bodoh; bahwa Allah maha kuasa, siswa lemah; bahwa Allah maha pengampun, siswa mengakui kesalahaan; bahwa Allah adalah Tuhan yang disembah dan "tempat" meminta, sedangkan siswa adalah ciptaan dan hamba yang butuh pada Allah. Agar siswa mampu meraih kesadaran semacam ini, siswa perlu disadarkan tujuan berdoa, mengetahui serta menghayati isi doa mereka, dan dilatih etika dan cara berdo'a yang benar.

2) Mengkorelasikan materi dengan ajaran Islam

Sebagaimana disebutkan sebelumnya, dalam aktifitas pembelajaran, subyek penelitian mengembangkan sikap religius siswa dengan cara menghubungkan materi pembelajaran Biologi kelas X dengan ajaran Islam. Ditinjau dari segi tujuannya, hal ini tidak sesuai dengan aturan Kurikulum 2013, sebab tidak ada satupun kompetensi sikap religius dari tiga kompetensi yang ditetapkan pemerintah dalam kurikulum 2013 bidang studi Biologi kelas X yang dikembangkan melalui aktifitas pembelajaran tersebut.

Tujuan aktifitas pembelajaran pengembangan sikap religius siswa yang dilakukan oleh subyek penelitian terfokus pada upaya penyadaran pada siswa bahwa materi yang mereka pelajari (Biologi) tidak lepas dari ajaran Islam, dan bahwa aturan Islam sesuai dengan temuan ilmiah. Padahal KD sikap religius Biologi kelas $\mathrm{X}$ adalah: mengagumi Tuhan melalui keteraturan dan kompleksitas mahluk hidup, mengagumi pola pikir ilmiah, dan konservasi lingkungan. ${ }^{26}$ Oleh karena itu, agar sesuai dengan kurikulum 2013, perlu dirancang ulang dan dilaksanakan pengembangan kompetensi religius siswa sebagaimana yang terdapat dalam KD sikap religius kelas X tersebut.

Ketidaksesuaian aktifitas pengembangan sikap religius yang dilakukan subyek penelitian dengan kompetensi sikap religius kurikulum 2013 disinyalir disebabkan keberadaan kompetensi sikap religius sebagai hal baru dalam pendidikan formal di Indonesia. ${ }^{27}$

${ }^{26}$ Salinan Lampiran 1 Peraturan Menteri Pendidikan dan Kebudayaan Republik Indonesia Nomor 59 Tahun 2014 tentang Kurikulum 2013 Sekolah Menengah Atas/Madrasah Aliyah, 99, diakses tanggal 9 September 2014 , http://jdih.kemdikbud.go.id/asbodoku/media/peruu/permen_tahun2014_nomor059.zip.

${ }^{27}$ Salinan Lampiran Peraturan Menteri Pendidikan dan Kebudayaan Republik Indonesia Nomor 66 Tahun 2013 tentang Standar Penilaian Pendidikan, 7, diakses tanggal 13 September 2014, http://pmp.dikdasmen.kemdikbud.go.id/files/peraturan/permen/04-b-salinan-lampiranpermendikbud-no-66-th-2013-tentang-standar-penilaian.pdf. 
Sebagai sebuah hal baru, kompetensi sikap religius selayaknya dijelaskan secara rinci dan detil dalam buku panduan atau pelatihanpelatihan kurikulum 2013, terutama dalam hal teknis pelaksanaan pengembangan kompetensi sikap religius dan penilaiannya. Ironisnya, merujuk pada buku-buku panduan pelaksanaan kurikulum 2013, penjelasan mengenai teknis atau metode pengembangan kompetensi sikap religius termasuk minim, singkat, dan tidak rinci, hanya berkisar pada pelaksanaannya dilakukan melalui pembelajaran tidak langsung dengan cara menjadikan kegiatan dalam pembelajaran langsung sebagai wahana untuk mengembangkan kompetensi sikap religius. ${ }^{28}$ Keadaan semacam ini tentu menyulitkan para guru dalam mengembangkan kompetensi religius siswa.

Meskipun tindakan subyek penelitian mengembangkan sikap religius siswa dengan cara mengaitkan materi pelajaran dengan ajaran Islam tidak sesuai dengan kurikulum 2013, hal ini tidak berarti metode ini jelek dan tidak perlu digunakan. Bahkan menimbang manfaatnya, metode ini sangat baik dan perlu dipertahankan. Sebab selain memperkaya ragam metode pengembangan sikap religius, metode ini juga dapat meningkatkan kadar keyakinan kebenaran agama Islam siswa. Berikut ini penjelasannya.

Saat guru menyampaikan relevansi temuan-temuan ilmiah dengan ajaran Islam, atau sebaliknya, relevansi ajaran Islam dengan temuan-temuan ilmiah, hal ini membuat siswa semakin yakin kebenaran ajaran Islam, dan imannya meningkat. Sebab keyakinan siswa diperkuat oleh ilmu pengetahuan dengan standar ilmiah. Kasus sejumlah ilmuwan Barat yang memeluk Islam karena menemukan kebenaran ilmiah dalam ajaran Islam menjadi bukti nyata manfaat metode ini dalam meningkatkan iman. ${ }^{29}$ Dalam praktek pembelajaran Biologi di kelas, sebagai contoh, di akhir pembahasan tentang macammacam bakteri, guru dapat menghubungkan hal tersebut dengan perintah Islam untuk menjaga kebersihan dan manfaatnya agar manusia tidak diserang bakteri jahat. Dalam istilah lain, agama Islam sesuai dengan akal.

${ }^{28}$ Salinan Lampiran IV Peraturan Menteri Pendidikan dan Kebudayaan Republik Indonesia Nomor 81a Tahun 2013 tentang Implementasi Kurikulum, 5.

29 'Mr.Jacques Yves Costeau: Masuk Islam Setelah Temukan Mukjizat 'Sungai di dalam Laut' , terakhir dirubah tanggal 12 Maret 2010, diakses tanggal 12 Agustus 2014, http://www.voaislam.com/read/citizens-jurnalism/2010/03/11/3797/mr.jacques-yves-costeaumasuk-islam-setelahtemukan-mukjizat-\#sthash.5QsBHShI.dpuf

Jurnal Pendidikan Agama Islam

Volume 4 Nomor 1 Mei 2016

ISSN(p) 2089-1946 \& ISSN(e) 2527-4511

Hal. 84 - 91 
Metode lain yang mirip dengan cara ini dan bisa menjadi metode alternatif mengembangkan sikap religius adalah dengan cara menghubungkan materi pembelajaran dengan Allah, Tuhan Pencipta dan Pengatur alam. Metode ini bila diterapkan akan bermanfaat dalam membangun kesadaran siswa bahwa segala hal terkait dengan Allah Yang Maha Pengatur dan Bijak. Dalam khazanah ilmu pendidikan Islam, pembelajaran semacam ini disebut sebagai kurikulum integral. 30

Dalam konteks pembelajaran Biologi, pola pembelajaran yang dilakukan subyek penelitian diatas dapat membuat siswa menyadari bahwa semua mahluk hidup -mulai dari tingkatan yang tinggi sampai yang rendah, baik yang kasat mata seperti gajah dan lebah, maupun yang kecil seperti virus dan bakteri- memiliki keterkaitan dengan Allah. Dampaknya adalah siswa merasa Allah senantiasa "ada" atau "muncul" dalam setiap aktifitasnya; saat ia belajar biologi, saat ia menjalani ujian akhir semester (UAS), saat siswa mengamati dirinya dan orang lain, saat ia mengamati binatang, dan sebagainya. Kondisi semacam ini membuat siswa merasa "bersama" dan "diawasi" oleh Allah, sehingga siswa menjadi segan berbuat maksiat.

Cara pandang bahwa segala sesuatu terkait dengan Allah sebagaimana disebutkan diatas disebut cara pandang tauhidi atau holistik. Cara pandang ini sering kali dilawankan dengan cara pandang sekuler atau dualistik, yaitu memandang urusan dunia terpisah dengan urusan agama. Ilmu pengetahuan dan urusan dunia tidak terkait dengan aturan agama, dan agama tidak boleh mengatur urusan dunia. Sebuah cara pandang yang terbukti menimbulkan banyak efek negatif bagi masyarakat seperti seks bebas, hedonisme, materialisme, kapitalisme, dan sebagainya. ${ }^{31}$

Meskipun metode kurikulum integral ini sangat bermanfaat guna meningkatkan sikap religius siswa, bila diterapkan tanpa persiapan yang baik malah dapat berakibat sebaliknya; menurunkan iman siswa. Untuk tema-tema tertentu yang nampak negatif, seperti penderitaan, kesedihan, virus atau penyakit mematikan, cacat fisik pada atau mental, dan bencana, guru harus hati-hati dalam mengaitkannya dengan Allah. Sebab jika guru tidak pandai

${ }^{30}$ Muhaimin dan Abdul Mujib,Pemikiran Pendidikan Islam (Bandung: Trigenda Karya, 1995), 2167.

${ }^{31}$ A. MananIdris, et al., Aktualisasi Pendidikan Islam; Respons Terhadap Problematika Kontemporer (Surabaya: Hilal Pustaka, 2009), 185. 
menjelaskan hikmah atau sisi positif dari hal-hal yang sering dipandang negatif tersebut, siswa akan marah, kecewa, menggugat Allah, dan menganggap Allah tidak adil atau tidak bijaksana. ${ }^{32}$ Oleh karena itu, khusus tema-tema semacam ini guru harus mempersiapkan diri dengan baik agar metode kurikulum integral tetap mampu meningkatkan iman siswa.

3) Menegur Siswa yang melanggar ajaran Islam

Dipandang dari aspek akademis, cara ini nampak aneh karena terkesan menggunakan metode pemaksaan kepada siswa dalam memilih atau melakukan sesuatu. Selain itu, metode ini tidak relevan dengan pencapaian kompetensi sikap religius kurikulum 2013.

Terlepas dari efektifitasnya dan kesan yang nampak negatif diatas, metode ini sebenarnya bagus untuk mengingatkan dan menyadarkan siswa akan aturan-aturan Tuhan dalam kehidupan mereka di sekolah. Sangat mungkin dalam kehidupan siswa di sekolah, mereka melakukan perbuatan yang melanggar aturan agama Islam, baik disengaja maupun karena ketidaktahuan. Dalam konteks inilah pentingnya teguran guru agar siswa tidak berbuat maksiat. Dalam istilah ajaran Islam, hal itu termasuk bagian dari aktifitas amar ma'ruf nahi munkar, mengajak pada kebaikan dan mencegah keburukan. Sebuah tindakan yang dipuji dan diperintahkan oleh Allah dalam alQur'an.33

Oleh karena alasan-alasan tersebut, penggunaan metode teguran guna mengembangkan sikap religius siswa dapat diterima dan layak dilakukan. Adapun rambu-rambu dalam melakukan teguran perlu diperhatikan agar maksud teguran dapat tercapai. Diantara rambu utama dalam guru melakukan teguran pada siswa adalah ayat al-Qur'an surat al-Nahl 125, yaitu mengajak kepada agama Allah dengan cara yang bijak, pelajaran yang baik, dan bila perlu dengan cara diskusi/debat yang dilakukan dengan cara yang baik pula. ${ }^{34}$

3. Hambatan Implementasi Pengembangan Sikap Religius Siswa melalui bidang studi Biologi kelas X di MAN 3 Malang

Berdasarkan wawancara dengan subyek penelitian, diperoleh informasi bahwa secara umum ia tidak merasa menghadapi hambatan yang berarti dalam

${ }^{32}$ Harun Yahya, Melihat Kebaikan dalam Segala Hal, Terj. Aminah Mustari (Jakarta: Senayan Abadi Publishing, 2003), 12.

${ }^{33}$ M. Quraish Shihab, Wawasan Al-Qur'an: Tafsir Maudhu'i atas Pelbagai Persoalan Umat (Bandung: Mizan, 1998),231.

${ }^{34}$ Depag RI, Al-Qur'an dan Terjemahnya (Bandung: CV Penerbit J-ART, 2005), 281.

Jurnal Pendidikan Agama Islam

Volume 4 Nomor 1 Mei 2016

ISSN(p) 2089-1946 \& ISSN(e) 2527-4511

Hal. 86 - 91 
mengembangkan sikap religius siswa melalui Kurikulum 2013 bidang studi Biologi kelas $\mathrm{X}$, kecuali dalam satu hal; aspek penilaian sikap religius.

Dalam implementasi penilaian sikap religius siswa, baik dalam perencanaan maupun pelaksanaan, subyek penelitian menghadapi hambatan yang cukup serius. Hambatan tersebut adalah tidak adanya panduan dalam menilai sikap religius siswa. Salah satu penyebabnya adalah karena hingga kini belum ada panduan dari sekolah maupun MGMP Biologi kota Malang.

Dampak dari ketiadaan panduan penilaian sikap religius siswa ini cukup signifikan, yakni subyek penelitian belum pernah membuat rencana penilaian sikap religius siswa, terlebih melaksanakan penilaian terhadap sikap religius siswa secara sunggu-sungguh dan sistematis. Hal ini didukung fakta berupa tidak adanya lembar penilaian sikap religius siswa di RPP yang dibuat oleh subyek penelitian.

Keadaan ini bila dibiarkan terus terjadi sangat mungkin berpengaruh pada kesuksesan pencapaian kompetensi sikap religius siswa, sebab tanpa adanya teknik dan instrumen penilaian sikap religius, akan sulit dilaksanakan penilaian terhadap kompetensi sikap religius siswa, apalagi mengukur kompetensi sikap religius siswa. ${ }^{35}$ Dampak lanjutan dari kondisi semacam ini adalah guru mengalami kesulitan dalam menentukan apakah pembelajaran untuk kompetensi sikap religius sudah tercapai atau belum.

Oleh karena itu, sebagai solusi jangka pendek, guru terkait perlu segera mencari contoh teknik dan instrumen penilaian sikap religius untuk ia adaptasi dan sesuaikan dengan keadaan siswanya. Adapun dalam jangka panjang, guru perlu mempelajari lebih sungguh-sungguh konsep dan teknik penilaian kurikulum 2013, untuk selanjutnya ia terapkan dalam mengajar. Dalam konteks ini, Kementerian Agama perlu mengadakan pelatihan cara penilaian sikap religius.

Terkait dengan penyusunan teknik dan instrumen penilaian religius, setidaknya ada dua hal penting yang harus diperhatikan guru: pertama, penentuan teknik dan instrumen penilaian hendaknya mengacu pada KD yang ingin diukur kompetensi pencapaiannya demi menghindari adanya kekeliruan dalam menentukan item-item penilaian; kedua, menyesuaikan teknik dan instrumen penilaian dengan jenis KD yang dinilai. Artinya, KD sikap religius harus dinilai menggunakan teknik dan instrumen penilaian sikap, bukan pengetahuan atau ketrampilan. ${ }^{36}$

${ }^{35}$ Salinan Lampiran Peraturan Menteri Pendidikan dan Kebudayaan Republik Indonesia Nomor 66 Tahun 2013 tentang Standar Penilaian Pendidikan, 1 dan 7.

${ }^{36}$ Salinan Lampiran Peraturan Menteri Pendidikan dan Kebudayaan Republik Indonesia Nomor 66 Tahun 2013 tentang Standar Penilaian Pendidikan, 4-5. 
Fenomena masalah kurangnya pemahaman terhadap aspek penilaian dalam kurikulum 2013 nampaknya merupakan kejadian umum di Indonesia. Staf Khusus Mendikbud Bidang Pengawasan dan Pengendalian Pembangunan (UKMP3), Agnes Tuti Rumiati, menyebutkan bahwa aspek yang kurang dipahami oleh guru dalam kurikulum 2013 adalah pendekatan saintifik dan proses penilaian yang dianggap rumit. ${ }^{37}$

Salah satu penjelasan logis munculnya permasalahan ini adalah banyaknya aspek yang perlu dipelajari dari kurikulum 2013, sehingga cukup menyita waktu, konsentrasi dan tenaga guru. Sebagaimana diketahui bahwa kompetensi dalam kurikulum 2013 berjumlah $4 \mathrm{KI}$ atau KD, dan masing-masing KD ini memiliki teknik serta instrumen penilaian yang berbeda. Belum lagi guru harus mendalami pendekatan saintifik agar bisa merancang pembelajaran yang membuat siswa aktif, menyusun RPP, dan sebagainya. Kondisi semacam ini potensial membuat sebagian aspek kurikulum 2013 tidak dimengerti guru, salah satunya adalah evaluasi kompetensi sikap religius siswa.

\section{Penutup}

Melalui proses identifikasi perencanaan, pelaksanaan dan hambatan, dapat diambil kesimpulan bahwa: pertama, perencananaan implementasi pengembangan sikap religius siswa dilakukan subyek penelitian melalui dua cara: penulisan rumusan tujuan pembelajaran untuk mengembangkan sikap religius siswa, dan penyampaian salam dan berdo'a di awal pembelajaran; kedua, pelaksanaan implementasi pengembangan sikap religius siswa dilaksanakan melalui empat cara: (a) penyampaian salam dan do'a di awal pembelajaran, (b) menghubungkan materi pembelajaran dengan aturan/ajaran Islam, (c) penyampaian salam dan berdo'a kafaratul majlis di akhir pembelajaran, dan (d) teguran terhadap siswa yang dianggap melanggar aturan Islam; dan ketiga, hambatan implementasi pengembangan sikap religius siswa adalah tidak tersedianya contoh atau panduan penilaian kompetensi sikap religius.

Adapun rekomendasi yang diusulkan adalah bahwa implementasi pengembangan sikap religius melalui bidang studi eksak seperti Biologi perlu ditingkatkan kualitasnya. Caranya adalah dengan mengikuti aturan yang terdapat dalam pedoman pelaksanaan kurikulum 2013, baik dalam hal penyusunan RPP, pelaksanaan pembelajaran, maupun penilaian. Selain itu, demi meningkatkan sikap religius siswa secara umum, pelaksanaan pengembangan sikap religius sangat perlu diperkaya dengan metode lain seperti penyampaian salam dengan penuh kesadaran, do'a mencari ilmu dan kafaratulmajlis yang dihayati, mengkorelasikan materi pembelajaran dengan ajaran Islam, dan teguran yang baik

37 “Tiga Masalah Guru dalam Implementasi Kurikulum 2013”.

Jurnal Pendidikan Agama Islam

Volume 4 Nomor 1 Mei 2016

ISSN(p) 2089-1946 \& ISSN(e) 2527-4511

Hal. 88 - 91 
pada siswa yang melanggar aturan agama. Dalam upaya mendukung hal tersebut, Kementerian Agama perlu mengadakan pelatihan dan pendampingan implementasi kurikulum 2013, khusususnya aspek pengembangan sikap religius siswa.

\section{E. Referensi}

A, D. Rancangan Pelaksanaan Pembelajaran (RPP) Matapelajaran Biologi Kelas X Tahun pelajaran 2014/2015.

Bogdan, R.C. \& Biklen, S.K. Qualitative Research for Education: An Introduction to Theory and Methods. Boston: Allyn \& Bacon, Inc., 1982.

Depag RI. Al-Qur'an dan Terjemahnya.Bandung: CV Penerbit J-ART, 2005.

Idris, A. Manan et al. Aktualisasi Pendidikan Islam: Respons Terhadap Problematika Kontemporer. Surabaya: Hilal Pustaka, 2009.

Kementerian Pendidikan dan Kebudayaan. Kurikulum 2013: Kompetensi Dasar Sekolah Menengah Atas (SMA)/Madrasah Aliyah (MA). Jakarta: TP., 2013.

Kunandar. Guru Profesional: Implementasi KTSP dan Sukses dalam Sertifikasi Guru. Jakarta: PT RajaGrafindo Persada, 2007.

Madjid, Nurcholish. Islam Agama Peradaban: Membangun Makna dan Relevansi Doktrin Islam dalam Sejarah. Jakarta: Paramadina, 1999.

Muhaimin, dan Abdul Mujib. Pemikiran Pendidikan Islam. Bandung: Trigenda Karya, 1995.

Al-Munawwar, Said Agil. Islam dan Masa Depan Umat. Jakarta: Zikrul Hakim, 2004.

Mursalim. “Do’a dalam Perspektif al-Qur'an” dalam Jurnal Al-Ulum vol. 11, no. 1, Juni 2011.

Pusat Kurikulum. Pengembangan dan Pendidikan Budaya \& Karakter Bangsa: Pedoman Sekolah. Jakarta: TP., 2009.

Sabiq, Sayyid. Fikih Sunnah 4. Terj. Mahyuddin Syaf. Bandung: PT. Alma'arif, T.thn.

Salinan Lampiran Peraturan Menteri Pendidikan Dan Kebudayaan Republik Indonesia Nomor 66 Tahun 2013 Tentang Standar Penilaian Pendidikan. diakses tanggal 13 September 2014, http://pmp.dikdasmen.kemdikbud.go.id/files/peraturan/permen/04-bsalinan-lampiran-permendikbud-no-66-th-2013-tentang-standarpenilaian.pdf. 
Salinan Lampiran 1 Peraturan Menteri Pendidikan dan Kebudayaan Republik Indonesia Nomor 59 Tahun 2014 tentang kurikulum 2013 sekolah menengah atas/madrasah aliyah, diakses tanggal 9 September 2014, http://jdih.kemdikbud.go.id/asbodoku/media/peruu/permen_tahun2014 _nomor059.zip.

Salinan Lampiran Peraturan Menteri Pendidikan dan Kebudayaan Republik Indonesia Nomor 65 Tahun 2013 tentang Standar Proses Pendidikan Dasar dan Menengah, diakses tanggal 13 September 22014, http://bsnpindonesia.org/id/wp-content/uploads/2009/06/03.-A.-SalinanPermendikbud-No.-65-th-2013-ttg-Standar-Proses.pdf.

Salinan Lampiran IV Peraturan Menteri Pendidikan dan Kebudayaan Republik Indonesia Nomor 81a Tahun 2013 Tentang Implementasi Kurikulum, 5, Diakses Tanggal 10 September 2014, http://luk.staff.ugm.ac.id/atur/bsnp/ Permendikbud81A-2013ImplementasiK13Lengkap.pdf.

Shihab, M. Quraish. Wawasan Al-Qur'an: Tafsir Maudhu'i atas Pelbagai Persoalan Umat. Bandung: Mizan, 1998.

Sugiyono. Memahami Penelitian Kualitatif. Bandung: Penerbit Alfabeta, 2010.

Wijayanto, Iip. Sex In The Kost. CV. Qalam: Yogyakarta, 2003.

Yahya, Harun. Melihat Kebaikan dalam Segala Hal. Terj. Aminah Mustari. Jakarta: Senayan Abadi Publishing, 2003.

“Gawat, 47 persen Pelajar Pengguna Narkoba”, terakhir dirubah tanggal 19 Februari 2011, diakses tanggal 12 September 2014, http://www.antaranews.com/berita/246764/gawat-47-persen-pelajarpengguna-narkoba.

"Mr.Jacques Yves Costeau: Masuk Islam Setelah Temukan Mukjizat 'Sungai di dalam Laut'”, terakhir dirubah tanggal 12 Maret 2010, diakses tanggal 12 Agustus 2014,

http://www.voa-islam.com/read/citizens-jurnalism/2010/03/11/3797/ mr.jacques-yves-costeaumasuk-islam-setelah-temukan-mukjizat\#sthash.5QsBHShI.dpuf

"Prestasi" Profil Madrasah, diakses tanggal 12 Agustus 2014, http://www.man3malang.com/tag/prestasi/page/1.

“Tiga Masalah Guru dalam Implementasi Kurikulum 2013”, dirubah terakhir tanggal 16 Oktober 2014, diakses tanggal 22 November 2014, http://news.okezone.com/read/2014/10/16/65/1052959/tiga-masalahguru-dalam-implementasi-kurikulum-2013. 
Harian Pagi Surya (edisi17 April 2011), 5.

Jurnal Pendidikan Agama Islam Volume 4 Nomor 1 Mei 2016 ISSN(p) 2089-1946 \& ISSN(e) 2527-4511 Hal. 91 - 91 